\title{
HISTORY OF THE USE OF COLCHICUM AND RE
MEDICAMENTS IN GOUT
WITH SUGGESTIONS FOR FURTHER RESEARCH
}

\author{
BY \\ EDWARD F. HARTUNG \\ New York City
}

(RECEIVED FOR PUBLICATION DECEMBER 22, 1953)

This brief history of the use of extracts of $\mathrm{Col}$ chicum autumnale in the treatment of gout had its origin in some research relative to the metabolism and mode of action of colchicine. It was interesting to review this history in order to develop a background, and thus to learn what ancient authorities and later observers knew about this drug. We shall review the evidence for the identity of certain plants thought by many investigators to be identical with our modern Colchicum autumnale, and which were described by early writers as poisons and later recommended in the treatment of gout; re-emphasize knowledge which has been more or less forgotten but which could be of experimental and practical usefulness to-day; delineate the fluctuations of popularity of colchicum as a treatment for gout during the past 1,500 years; and briefly mention the history of its uses in other fields of research. At the present time colchicine and its derivatives, as well as other mitotic-arresting drugs, are of considerable importance in the field of cancer research. More thoroughly established, however, is the role of colchicine in the treatment of acute attacks of gout, and it is this latter role that concerns us most here.

In the preparation of this study we have received invaluable assistance from Professor William $\mathbf{H}$. Stahl, Chairman of the Department of Classics of New York University, who translated some of the Greek and Latin of the original manuscripts; and from the Inaugural Dissertation of Doctor Kurt Rüegg of Basel (Rüegg, 1936), on which we have relied heavily for our discussion of the mediaeval period. A résumé by Sharp (1909) has also been of some help, as has the work of Schnitker (1936).

\section{The Drug Colchicine}

To-day, in the treatment of acute attacks of gout, colchicum is administered as the relatively pure colchicine. The original structural formula elucidated by Windaus (1924) has been shown to be incorrect. The formula proposed by Dewar (1945), where colchicine contains a tropolone ring system is now accepted and has received experimental $\vec{\omega}$ justification (Arnstein and others, 1948, 1949; $\omega$ Čech and Šantavý, 1949; Doering and Knox, 1951).

The drug is given by mouth in tablet form, $\bullet$ 0.01 gr. each, at the onset of a gouty attack, and 을 then every hour for five to ten doses until diarrhoea is induced. Usually at the onset of the diarrhoea $\mathscr{D}$ the acute joint begins to resolve. In chronic gout $\frac{D}{0}$ some advocate its use in doses of $0.01 \mathrm{gr}$. once or $\mathbb{\mathbb { D }}$ twice a day over a prolonged period of time. Intravenous colchicine also has its advocates. Tinctures and wines of colchicum are to-day considered les $\overrightarrow{0}$ desirable because of the possible variability in the $\$$ drug content. The new hormones cortisone ari ACTH have by no means usurped the ancient and useful position of this drug.

The mode of action of colchicine in gout is still a mystery. The most important known effect of $\stackrel{\square}{\square}$ colchicine, which is to inhibit the completion of $\overrightarrow{\vec{A}}$ mitosis or the division of cells, holding the process in $\frac{\circ}{3}$ what is called the metaphase, may or may not be related to the favourable effect of colchicine in an acute attack of gout. Proper spindle fibres necessary to normal cell division fail to develop. The chromosomes may divide in spite of the failure of cell $\frac{\sigma}{3}$ division, thus giving rise to polyploidy or multiple sets of chromosomes. In larger doses not only do $ᄋ$ the dividing nucleii fail to produce the spindle but $₹$ the chromatic material becomes pyknotic and $\frac{9}{9}$ degeneration of the cell proceeds.

The effect on mitosis is induced by 0.001 of the amount necessary to produce other observable $N$ metabolic effects on the cell, and its remarkably $\Omega$ selective action is shown by the fact that the nuclear $\tilde{O}$ effects of other compounds are far less marked. To ్ㅓㅇ induce comparable effects with sodium cacodylate $\bar{O}$ for example, one must use dosages a million times as great.

Anton Stoerck and others recognized a diuretic $\stackrel{?}{?}$ effect, and this has recently been investigated by $T$ 
Dicker (1951). Hormone (Havas, 1938), enzyme, shock-like effects (Selye, 1949), and a reduction of vitamin $\mathrm{C}$ content of tissues, have all been postulated. Colchicine is moderately bacteriostatic (Gohar and Makkawi, 1951). It apparently has no effect on uric acid excretion. Its effect or lack of effect on uric acid metabolism awaits elucidation.

The unique poisonous effects of colchicine, of importance in this historical study, have been known since ancient times. There appear to be two distinct actions. First are the immediate irritating effects on gastro-intestinal tract, possibly by exciting the nerve endings to smooth muscle (Jacobj, 1890), but more likely' through a central effect (Ferguson, 1952). Its action in this regard can be compared to that of muscarine, pilocarpine, and physostigmine. Secondly, colchicine, even in relatively enormous doses, produces a lethal effect slowly, requiring 3 to 6 hours to cause death in carnivora and longer in herbivora. This delay may be due, as in bacterial toxins, to a delay in absorption into the central nervous system (Dixon and Malden, 1908; Dixon, 1915) or, as Brues suggests (personal communication), to the possibility that the lethal action is associated with a metabolic factor such as the disappearance or accumulation of a critical metabolite. Death is apparently caused by vasomotor and respiratory paralysis. Hamsters do not succumb to colchicine poisoning (Orsini and Pansky, 1952).

Toxicity studies on poikilotherms, in whom the body temperature closely parallels the environment, show that these cold-blooded animals have remarkable tolerance to colchicine (Fuhrman, 1946), frogs requiring a dose of $100 \mathrm{mg}$. to 1 gram to prove fatal. However, the frog may be rendered much more sensitive by placing it in an incubator for a few days before the administration of the drug. Such preheated animals die with doses of 0.1 to $1 \mathrm{mg}$., but only after a delay of 2 to 5 days. The toxicity of colchicine in frogs was increased 400 to 500 times when the temperature was raised from $20^{\circ}$ to $32^{\circ} \mathrm{C}$. (Fühner, 1913; Sanno, 1911).

The present-day supply of colchicine in the United States is derived mainly from botanical drug concerns who import the seeds and corms of the plant Colchicum autumnale from the temperate regions of Europe and from North Africa. This is due to economic factors, as our native corms should be just as productive. This material, received in a dry state, is treated with various solvents, more or less following the methods of extraction, purification, identification, and assay described in the U.S. Pharmacopeia. Further purification by chromatography can be accomplished by the method of Ashley and Harris (1944). Colchicine U.S.P. is said to contain 4 per cent. desmethyl-colchicine (Horowitz and Ullyot, 1952).

\section{The Plant Colchicum}

Colchicum autumnale is a perennial plant of the Lily family, to which belong Lilium convallium (Lily of the Valley) and Veratrum (Hellebore), the latter plants also being of some importance in this study. It is known popularly under many names, in English as Wild Saffron, Meadow Saffron, Autumn Crocus, Naked Lady, Naked Boy, and Son before the Father. In Central Europe it is called Herbstzeitlose and by many other names. It grows in most parts of the temperate areas of Europe, Asia, and America, at times growing wild in moist meadows.

The corm as obtained from the seed shops is a white, bulbous, mealy-like mass about $3 \mathrm{~cm}$. wide by $5 \mathrm{~cm}$. high, covered with a brownish red tunic. Below are the filiform roots. These corms are planted in September or October (Fig. 1a). Shortly thereafter new corms, one or more, develop along grooves in the old, and about the first frost these new corms send up a tube unaccompanied by leaves or seeds and produce a flower (Fig. 1b), usually lilac-coloured. Thus the name "Son before the Father" (the flower before the leaves and seed). The flowers last a few weeks and then fade and nothing is seen again until June, when the new corms send up many coarse, luxuriant, lanceolate leaves, about a foot long, and shortly thereafter the seed capsule (Fig. 1c). The old original corm has meanwhile been disintegrating. By mid-July the leaves and capsules wither and disappear, and by October the new corms are ready to go through the cycle again.

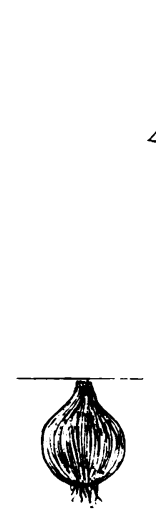

(a)
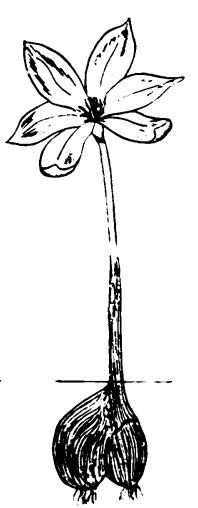

(b)

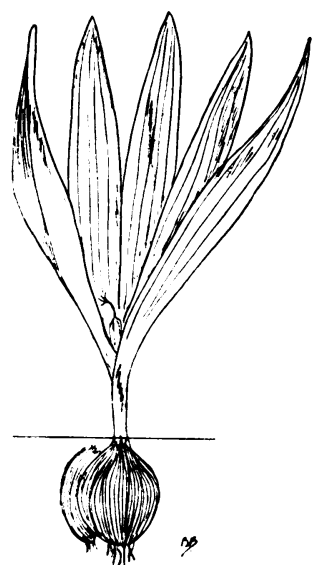

(c)
Fig. 1

(a) Bulb.

(b) Autumn flower from new bulb.

(c) Spring leaves from enlarged new bulb, the original bulb being now shrunken. 
Colchicine is present in all parts of the plant, but particularly in the corm $(0.35$ per cent.), seeds $(0.45$ per cent.), and flowers $(0 \cdot 80-0 \cdot 81 *$ per cent.). The seeds are collected in June and July and the corms in July and August, or during flowering time, when they are considered to be the most rich in colchicine, although there is scant experimental evidence for this. Other plants known to contain colchicine are Androcymbium gramineum (Perrot, 1936), Gloriosa superba and species of Merendera (Mehra and Khoshoo, 1951), and Gloriosa Rothchildiana (Bryan and Lauter, 1951).

Colchicum autumnale may be confused with members of the Crocus family, particularly the Autumn Crocus, but it can be easily distinguished from them by the fact that the crocuses are of the Iris family, having three stamens, whereas the colchicums have six. Colchicum autumnale is only one of many colchicums. There are some thirty species of the genus (Krythe and Wellensiek, 1942), including a few spring-flowering varieties, all of which produce colchicine.

To use the terms Meadow Saffron or Saffron Crocus as synonymous with colchicum is confusing in that these terms suggest the Crocus sativus, a plant well known to the ancients, and described by Dioscorides, which has been throughout the ages the source of saffron, a medicinal drug, a perfume, a flavour, and a brilliant yellow dye. Crocus sativus is of the Iris family and has no relationship to the colchicums. It is still considerably cultivated in Spain and to some extent in America and England, but the large industry at Saffron Walden in England is a thing of the past (Bowles, 1924).

\section{Nomenclature}

In the history of colchicum four other terms continually recur: "Ephemeron", "Hermodactyl", "Surugen", and "Herbstzeitlose". The question is whether these are, or are not, synonymous. If not, what are the present names of the plants represented by these terms?

Ephemeron.-The extant records of the history of colchicum probably start with Theophrastus of Eresus (370-285 B.C.), the first botanist whose writings have come down to us, who, in his "History of Plants" under the term Ephemeron, described a poison with an effect which may be delayed for a considerable interval, thus probably explaining the derivation of the name. Theophrastus describes the plant as having leaves like the hellebore or lily, but gives no further botanical details.

Any relationship to colchicum probably would not have been considered were it not for the fact that

\footnotetext{
* These figures are variable and not constant.
}

Nicander (c. 150 B.c.) in his "Alexipharmaca", a work on plant poisons and their antidotes, also refers to ephemeron, again as a poison only.

"Ephemeron", he says, is "that destructive fire of the Colchican Medea."

Thus the origin of the word colchicum, after the ancient district of Colchis on the Eastern shore of the Black Sea, a region associated in the Greek mind with all kinds of sorcery. Nicander's description of the baleful effects of his ephemeron is also not inconsistent with what one might expect from poisoning with colchicum. However, the effects of the poison used by Medea to avenge herself on her rival, at least as described by Euripides, do not suggest the action of colchicum. The Greek scholium to Nicander, written later, but at an undetermined period, states that "Ephemeron-is called Colchicon".

The "Materia Medica" of Dioscorides (1st-2nd cent. A.D.), as it has come down to us in the "Julianae Aniciae Codex", transcribed before 512 A.D. as a wedding present for the daughter of Anicius Olybrius, Emperor of the West, and now available in a photostat edition, speaks of "Ephemeron, which some call Colchicon", making the two terms synonymous. It then gives a description (on folio 105) of a poison which could very well be the modern colchicum.

"Some call the plant Colchicon, others call it Bolbos. The Romans call it Bulbus agrestis. As the autumn is drawing to a close, the plant puts forth a whitish flower, like the flower of the Crocuss Later it bears leaves somewhat like those of the Bulbus, but shinier. It has a stalk a span long and reddish seeds; its root has a tawny skin verging int black. When peeled, the root is found to be white, tender, full of juice, and sweet. The plant has its diaphysis at about its middle, from which point it sends forth its flower. The plant is found chiefly in Messenia and Colchis. When eaten, it has a fatal effect by choking, as is the case with mushrooms. We have described the plant so that no one may confuse it with the edible Bulbus and eat it by mistake. It has a strange attraction for the unwary because of its pleasant taste. To those who have eaten of the plant, drinking cow's milk offers relief, as it does to those who have eaten poisonous mushrooms. Whenever there is cow's milk at hand, there is need of no other antidote."

The "Cheltenham Dioscorides Codex" [late 9th or early 10th cent.; original in Pierpont Morgan LibraryMorgan MS. 652] confuses the issue by discussing two Ephemerons, the last (on leaf 311 verso) as an "Ephemeron which some call Agrestis iris", here describing an entirely different plant, which is "non-poisonous" and recommended for toothache and swellings.

In the English translation of Dioscorides (Goodyer, $\sigma$ 1655; ed. Gunther, 1934), the terms are reversed, and the N chapter on the poisonous variety begins "Colchicum, N which some call Ephemeron". Gunther does not state the "C name of the Codex translated by Goodyer, but the illustrations are obviously taken from the "Julianae 0 Aniciae Codex".

It is clear from the above that writers of the Dioscorides $\stackrel{?}{+}$ codices considered that there were two kinds of Ephe- $T$ 
meron, one "which some call Colchicon", probably the present-day colchicum, and another totally different, non-poisonous plant, apparently an Iris, recommended for toothache and tumourous swellings.

The section in the "Julianae Aniciae Codex" dealing with the "Ephemeron, which some call Colchicon", and that in the "Cheltenham Codex", are each accompanied ' by an illustration (Figs 2 and 3). These are fairly accurate representations of colchicum, but the plant is shown with leaves and flowers together, a phenomenon which does not occur with Colchicum autumnale or with the Colchicum variegatum of the Middle East. It may be a springflowering variety or the artist may have wanted to depict the various stages of the plant's growth in one diagram.

Scribonius Largus (c. A.D. 14-54) copied Nicander, adding nothing to the subject. Pliny the elder (A.D. 2379) in his "Natural History", described the ephemeron, referring to it as the Iris agrestis of Dioscorides, and did not mention the poisonous ephemeron or colchicum. Galen (A.D. 131-201) speaks of "Ephemeron, not the poisonous plant which is also known by the name of

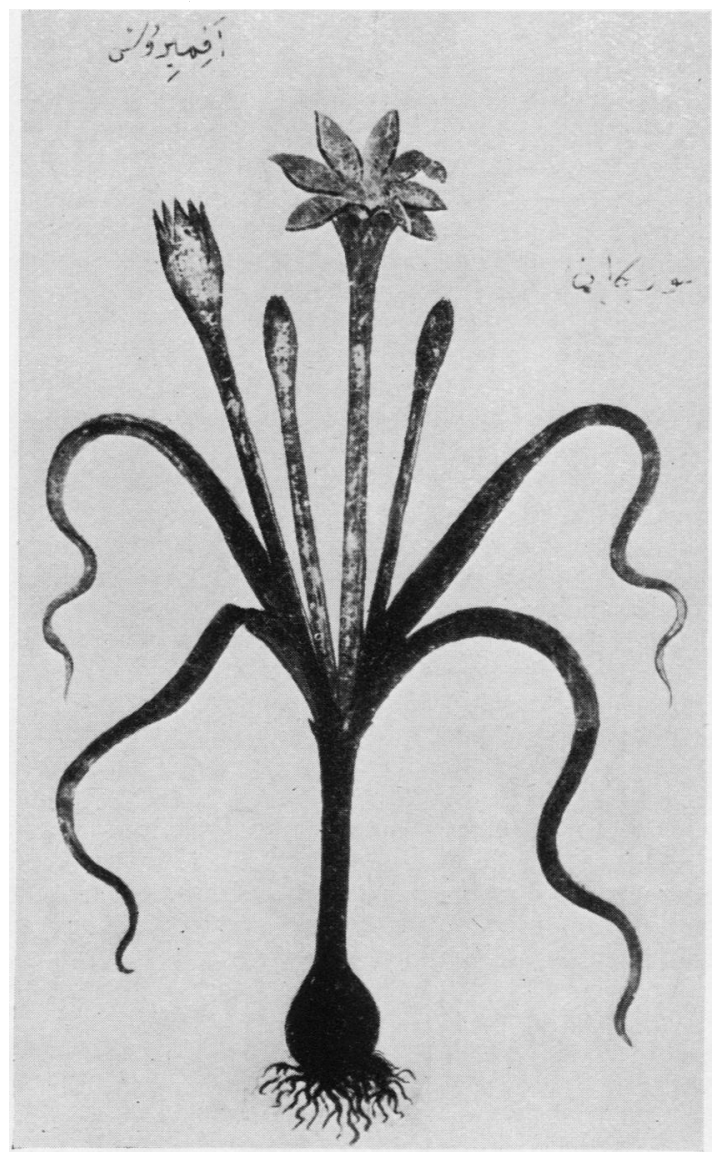

Fig. 2.-Ephemeron or Colchicon, from the Codex Julianae Aniciae, 104 verso.
Colchicum, but the other which is called Iris agria", and does not discuss colchicum itself either as a poison or as a drug. Aretaeus ( 2 nd cent. A.D.), who wrote a most penetrating description of gout, says that "in gouty cases Hellebore is the great remedy". The leaves of hellebore or veratrum can be confused with those of colchicum. Aretaeus recommends the iris also, but does not mention either colchicum or ephemeron. Oribasius (4th cent. A.D.) copies Galen; he discusses the nonpoisonous ephemeron, "not the poison which some call Colchicum".

Up to this point, then, it would appear that the ancients knew of a plant which they called "Ephemeron or Colchicum". It was poisonous and similar in its appearance and effects to the modern colchicum, and had for them no useful place in medicine. Another plant, also sometimes called ephemeron but never colchicum, is described as non-poisonous; it is sometimes called the Iris agrestis (Wild Iris), and was used in medicine for toothache and tumours.

Hermodactyl.-Alexander of Tralles (c. A.D. 550), in his "Therapeutica" made no mention of either ephemeron or colchicum. In his masterly discussion of gout, he recommended hermodactyl (Hermes for Mercury and dactylus, a finger) as a drug of choice. He gave no botanical description and its real identity is still a matter of dispute. He applied hermodactyl as we should colchicum to-day, giving it for gout, primarily for acute

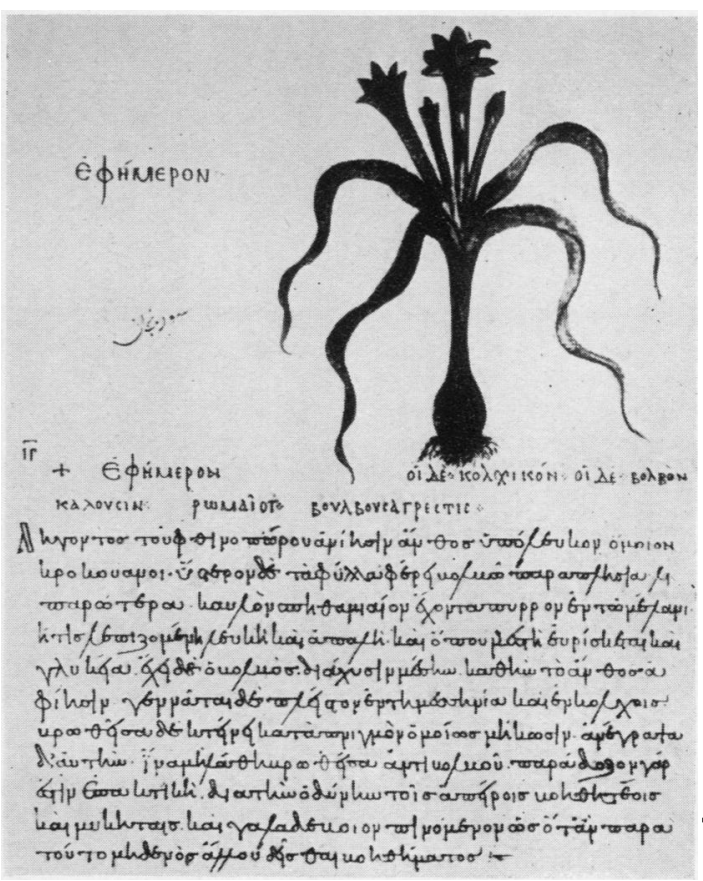

Fig. 3.-Ephemeron or Colchicon, from the Cheltenham Codex. Plate 48. 
attacks. The patients "declare that they get rid of their pain immediately because this medicine eliminates the toxic material with the stool movements, and the sick person can walk". He noted its cathartic effect, particularly warning against its irritating action on the stomach and intestines, and gave many prescriptions containing hermodactyl, preferably in pill form, with carminatives and cathartics added "in order to counteract the untoward effects on the gastro-intestinal tract". The evidence in favour of identifying hermodactyl with colchicum is first that the indications and effects appear similar, and second that Alexander does not once mention colchicum or ephemeron, a notable fact in that he was naturally familiar with the "Herbal" of Dioscorides.

Paul of Aegina (7th cent. A.D.), in his "Epitome", mentioned all the terms so far discussed: Ephemeron, "which some call Colchicum (because it grows in Colchis) or Bulbus silvestris", which is designated as a poison as in Nicander and Dioscorides; and again Ephemeron, "not the poisonous species but that which is called Wild Iris"; and lastly Hermodactyl, saying that "the root of it is possessed of purgative properties", and it is good "for affections of the joints in rheumatism", and bad for the stomach.

Paul of Aegina made a clear differentiation between the three terms so far discussed. In addition, he mentioned "recourse to preparations of Saffron", as distinct from the above three. We cannot be sure, however, whether Paul knew for a fact that all three were different, or whether he was merely copying from the texts of Dioscorides, Alexander, or others, without any personal knowledge of the subject. He himself admitted that he was not an original writer, but merely an eclectic.

References to colchicum and related terms in the Western world during the Middle Ages appear to be few. For example, Gilbertus Anglicus (1170-80? to 1230) refers to formulae called "Pilulae Artheticae Salernitorum", "Pilulae Arabice", etc., the active ingredient of which was a root he called hermodactyl.

Surugen.-The Arabic writers introduced a new term, "Surugen", with many variations of spelling. John Mesue (928-1018), in his "De re medicina libri tres" (Rüegg, 1936), spoke of "the Hermodactyl or Surugen", making the two synonymous. Mesue recommended it particularly for diseases of the joints and was the first to mention that the corm must be dried for 6 months before being used, fresh corms being "extremely poisonous".

Abu Mansur (10th cent. A.D.) spoke of "Surindschan" (Rüegg, 1936). Avicenna (980-1037) referred to "Hermodactyl or Surengian" and stated that it was a root with white or yellow flowers, was good for podagra, and, as recommended by Alexander of Tralles, was best given with carminatives and cathartics.

Other Arabic writers are mentioned by Rüegg (1936); Ibn-El-Beithar (1197-1248), for example, considered Hermodactyl and Surugen to be identical, but Serapion Junior (11th cent. A.D.) is most notable for our purpose because he made all the terms synonymous. Serapion said that "Surugen is Hermodactyl" and that "Hermodactyl, which is also called Achimeron" is similar to the
Saffron, has leaves like the onion, a stem one span long, and a white root with a red cover, the root being soft, sweet, and toxic as mushrooms. He recommended cow's $\frac{\square}{\omega}$. milk as an antidote (as did Dioscorides), and stated that it was used as a treatment for arthritis. Serapion, then, $\overrightarrow{\overrightarrow{\mathrm{F}}}$ in making completely synonymous all the three terms sofar discussed, is exactly contrary to Paul of Aegina. As $\frac{-}{0}$ far as we can determine he was the first to state (although $\overline{\bar{c}}$ it may have been common knowledge) that ephemeron or $\frac{\vec{D}}{(\mathbb{D}}$ achimeron had a place as a medicine and not as a poison $\unrhd$ only, that it was valuable in the treatment of arthritis, and that it was synonymous with hermodactyl and surugen. $\rightarrow$ His words were apparently unchallenged for the next? 500 years, when he was attacked on this point, par- $\vec{\omega}$ ticularly by Euricius Cordus (see below).

At the same time hermodactyl, and not surugen, was still the term of choice in the Byzantine Empire. In a treatise on gout written for the Emperor Michael $\vec{\omega}$ Palaeologus (c. 1282 A.D.) by Demetrius Pepagomenus, $\omega$ are prescriptions for hermodactyl pills, mixed with $\vec{\varphi}$ cathartics such as aloes and carminatives such as licorice or cinnamon, to render them "agreeable to the stomach". 음

Herbstzeitlose and Colchicum Autumnale.-By the time $\mathcal{\Phi}$ of the Renaissance a new term had appeared in Central $\frac{\mathbb{D}}{\mathrm{O}}$ Europe-“Herbstzeitlose", variously spelled and pos- $\overrightarrow{\mathbb{D}}$ sibly meaning "without time" or "out of season", though $\frac{\partial}{\sigma}$ many other derivations have been offered. It is a term $\mathbb{D}$ which undoubtedly arose in the vernacular and was the $\vec{\theta}$ gradually incorporated into the herbals. Botanical aw medical writers soon began to use it as synonymous with the other terms discussed above.

Hieronymus Brunschwig (1450-1539), an Alsatian army surgeon, in his "Distillierbuch", for example, said $\frac{\partial}{\circ}$ that "wild saffron is the corm of Hermodactyl or Zeitlose". He followed Mesue in stressing the fact that it is dangerous if not dried long enough. The "Hortus Sanitatis" (Rüegg, 1936), a herbal with many wood-cuts, $\overline{\overline{0}}$ published in Mainz in 1485, made the problem appear 3 quite simple by stating that the zeitlose was the hermodactyl of the Latins, the achimeron or colinticon of the Greeks, and the sturagen or Surumen of the Arabs, and that it was good for gout and dropsy and might be used externally with benefit in a number of conditions. $\frac{\sigma}{5}$ Other authors, including Otto Brunfels (1488-1534), one of the fathers of botany, who wrote an "Herbarium or 8 Lexicon of Medical Simples", also stated that these terms were synonymous.

A contrary opinion, however, may be seen in the writings of Euricius Cordus (1486-1535), a physician and $\frac{7}{2}$ botanist, who pointed out that Paul of Aegina put hermodactyl in a separate category from ephemeron and $N$ colchicum. Cordus thought that Serapion and many subsequent writers had erred in saying that these were $N$ synonymous terms.

Other early herbalists and botanists, and particularly $\sigma$ students and translators of Dioscorides, attempted to identify these ancient terms (Rüegg, 1936). Thus, Caspar Bauhin (1550-1624), author of the famous "Pinax", said $\$$ that hermodactyl and colchicum were identical. Leonhart Fuchs (1501-1564) thought the non-poisonous ephemeron 
to be Lilium convallium (Lily of the Valley). Mattioli (1501-1577), the translator of Dioscorides into Italian, after receiving a specimen designated as hermodactyl from Constantinople, concluded that the hermodactyl of his age and of the ancients was not Colchicum autumnale, but Orchis maculata (Palmae Christi) or possibly Iris tuberosa. Carl Linnaeus (1707-1778), more or less following Mattioli, distinguished a Hermodactyl verus, and said it was probably an Iris tuberosa but "might be" the Colchicum autumnale.

Thus we see that the Arabs apparently accepted the opinion that the terms were synonymous, while during the early mediaeval period the Western world seemed silent on the subject. From the 15th century, however, the argument raged vigorously as to the identity of these terms. Unless new evidence is uncovered it seems doubtful whether the controversy will ever be settled. It is the author's opinion that the circumstantial evidence is in favour of the terms being identical.

The works of Alexander of Tralles (6th cent. A.D.) contain the first record of the use of colchicum in gout, assuming colchicum and hermodactyl to be identical. As hermodactyl, the drug, was used in gout in the Byzantine world, and as surugen it was used by the Arabic physicians. As hermodactyl it appeared in the earliest English literature, and as herbstzeitlose in that of Central Europe.

\section{Administration in Gout Renaissance Period and Later}

During the Renaissance there were occasional references to these drugs as useful in gout. But in general the opinion had somehow arisen and was generally accepted in the Western world that they were extremely dangerous and even useless. Jaques Greven, for example, the translator of Nicander into French, wrote to Queen Elizabeth in 1568 that "this poison is the enemy of man's nature'" Hieronymus Bock (1498-1554) in his "Kreutterbuch" said that it was dangerous and made the gout worse; Rembertus Dodonaeus (1517-1575) reported that it was poisonous and useless; Mattioli warned against its use internally. In spite of this reputation, however, it was obviously stocked by the pharmacies of the time, though its exact application in medicine is not clear. The commodity called hermodactyl appears to have been imported from the Orient, especially Constantinople, in spite of the fact that herbstzeitlose was common in the fields of Europe and England.

An idea of the poor opinion in which the drug was held may be gathered from a few examples from the 17 th century. During this period such an eminent physician as Thomas Sydenham (1624-1689), who wrote one of the classic descriptions of gout, made no mention whatever of any of the possible names of this drug. He was opposed to the treatment of gout with drugs which acted on the bowel, but on the other hand recommended sassafras, elecampane, sarsaparilla, angelica, wormwood, opium, and others. Nor did Nicholas Culpeper (1681), in his famous "Herbal", mention this drug at all.

During the 18 th century numerous medical books appeared with sections on gout and special dissertations on the subject (Lewis, 1761; Home, 1780; Blackmore, 1726; Hill, 1769; Cadogan, 1772; Heberden, 1802; and Kinglake, 1804), but none mentioned colchicum or hermodactyl. Horace Walpole wrote endlessly on gout and its treatment, but never on colchicum. Benjamin Franklin had gout himself and refers to its treatment, but makes no mention of the drug. Stephen Francis Geoffroy considered colchicum, Herbstzeitlosen knollen, and hermodactyl as all synonymous, but described their use only as magical amulets against epidemics.

On the other hand there were some exponents of the use of the drug, including Ambroise Paré (1517-1590), who made use of the "hermodactyl" in gout, Walther Hermann Ryff (1573), who said that the zeitlose was identical with hermodactyl and very useful in gout, and John Quincy (1733), author of the "Complete English Dispensatory", who looked on hermodactyl as a species of colchicum and called it, among other things, "the soul of the joints".

The London Pharmacopoeias of 1618, 1627, 1632, and 1639 listed "Radix Colchici s. Hermodactyl". However, the 1639 edition was the last to mention either colchicum or hermodactyl, and neither name appeared again for over 150 years, until in the 1788 edition colchicum was again listed (probably as the result of the writings of Stoerck (1764)), and hermodactyl was dropped forever. Colchicum autumnale was official in the Swiss Pharmacopoeia of 1771, and under the name of Hermodactyl it was official in the French Codex of 1761.

\section{Modern Recognition of Colchicum}

The modern era of the use of colchicum probably starts with Baron Anton Stoerck, who wrote a book on the use of Colchicum autumnale or Meadow Saffron in dropsical conditions and particularly in pleural effusions. Stoerck has been credited with the reintroduction of the use of colchicum for gout, but this is, as far as we can see, an error, in that Stoerck never applied the drug to the treatment of joint conditions. Its use in dropsy, already known to the Arabic physicians (see above), is most interesting in view of recent investigations into the diuretic effect of some mitotic-arresting drugs, 
particularly colchicine. Later authors spoke highly of the synergistic action of digitalis and colchicine in the improvement of dropsical conditions, when digitalis alone failed to be effective (Hammond, 1861). Dicker (1951) has recently demonstrated on rats the water-eliminating action of colchicine.

The use of colchicum in gout was reintroduced, it appears to me, by Nicolas Husson, not a physician but a military officer in the French Army, who in the latter part of the 18th century concocted a panacea which he called "Eau Medicinale". This secret remedy had a great vogue in Europe and for many years its ingredients were the subject of controversy (Husson, 1783). The cases of gout described by the inventor are not so numerous as those of other diseases.

"Eau Medicinale" was introduced into England in 1808. There were a number of imitations, such as "Wilson's Tincture" and "Reynolds' Specific". Edwin Godden Jones (1810), said that "Eau Medicinale" had been discovered about 40 years earlier by Nicolas Husson, a military officer in the service of the king of France:

"We are informed by himself that in the course of researches to which his propensity led him, he discovered a plant before unknown in medicine, which upon examination, was found to possess extraordinary virtues in the cure of various diseases."

From the beginning the concoction met with much opposition:

"The clamours against it became at length so loud, that the sale of it was suppressed in Paris, in 1778 , by an order from the police. This prohibition was removed on the fifth day."

Want (1814), after considerable experimentation and observation, stated that the main ingredient of "Eau Medicinale" was a venous infusion of colchicum corm; he called the attention of the medical profession to the influence of colchicum itself in the treatment of gout. Want was followed by other authors, such as Clark (1818). Sir Henry Halford (1831), thought highly of colchicum in gout, and, like Mattioli before him, sent to Constantinople for specimens of hermodactyl, and proved to his own satisfaction that they were identical with Colchicum autumnale. Home (1817), brother-in-law of John Hunter, and the man who, according to Garrison, burned Hunter's manuscripts and then used the material as his own original work, had gout himself, experimented with "Eau Medicinale" and colchicum and stated that colchicum was a "specific" remedy for gout and was the main ingredient of Husson's formula. To this Scudamore (1819), in his "Treatise on the Nature and Cure of Gout and Rheumatism" and other writings, somewhat reluctantly agreed, and from that time on the study and use of colchicum belongs to contemporary history.

The reintroduction of colchicum was attended by $\frac{}{\omega}$. over-enthusiasm; thus, Haden (1820) and Maclagan (1852) gave a long list of asserted indications. The latter gives an extremely interesting and impartial 0 survey on the subject, equal to his penetrating remarks on rheumatic fever. Moderation was again $\frac{\bar{\rho}}{\sigma}$ restored by the publication "The Nature and Treat- $\stackrel{\mathbb{\Omega}}{\varrho}$ ment of Gout and Rheumatic Gout" (Garrod, 1859). ¿ Almost all our pertinent knowledge of colchicum is ? to be found in Garrod's classical descriptions. The only important aspect not known to Garrod $\overrightarrow{\vec{\omega}}$ was the drug's effect on mitosis. Garrod, like the o ancients, recommended that a cathartic such as $\frac{0}{2}$ calomel be administered with colchicum.

Since Garrod's time very little of a positive nature $\vec{\omega}$ has been added to our knowledge of the use and mechanism of action of colchicine in acute gout. $\&$ Garrod (1848) had shown and verified that there $ᄋ$ was an increased amount of urates in the blood of gouty subjects, but that colchicum did not affect the $\delta$ blood level or excretion of urates. Theoretical $\frac{\mathbb{D}}{0}$ explanations of its action (as an enzyme, as a hor- $\frac{\mathbb{D}}{3}$ mone, as a "shock drug" acting through the pituitary-adrenal axis, or as inhibitor of uric acid synthesis) have been repeatedly proposed but withogit $\overrightarrow{0}$ good experimental evidence. The attractive hype thesis that the mechanism of action in gout is in sorie way related to the phenomenon of mitotic arrest induced by colchicum is also without any support $\frac{\partial}{\partial}$ whatever.

Colchicum had been isolated by Pelletier and $\frac{\circ}{\triangleright}$ Caventou (1820). Geiger (1833) had extracted a $\underset{F}{\rightleftharpoons}$ fairly pure colchicum and called it colchicine. Zeisel $\frac{0}{3}$ (1883) elucidated the chemistry still further and worked out its empirical formula $\left(\mathrm{C}_{22} \mathrm{H}_{25} \mathrm{O}_{6} \mathrm{~N}\right)$. Houdès $(1881,1884)$ accomplished further purification. Jacobj (1890) wrote extensively of its properties. Šantavý and Reichstein (1950) have isolated four other colchicine-like substances from the seeds of the plant, but their properties are as yet unknown.

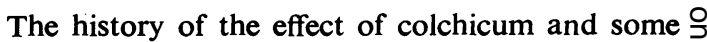
47 other chemicals (Krythe and Wellensiek, 1942) in inducing mitotic arrest has profound significance in cancer research, as well as in many other fields, N such as endocrinology, genetics, and cytology, but this work is not within the scope of this summary. 0 Of the 47 (which include acriflavine, podophyllo- $\mathbb{W}$ toxin, and auramine), colchicine is unique in that, as mentioned above, it acts in dosages far below the 0 levels that would interfere with general cell meta- $\bar{\varnothing}$ bolism. In suitable doses it inhibits only the meta- $\stackrel{?}{+}$ phase. The literature on this subject is extensive 0 
indeed, the bibliography of Eigsti (1947) taking up 48 pages.

Dustin and Grégoire (1933a, b) observed the effect of arsenical and other compounds on nuclear division in grafted mouse tumours. Lits (1934), working in Dustin's laboratory at the University of Brussels, reported on the general cellular reactions and "lesions" caused by colchicine in animal cells. Amoroso (1935) observed the beneficial effect of colchicine on the malignant growths of patients treated primarily to relieve acute attacks of gout and tested the efficacy of colchicine on malignant tumours in animals. Ludford (1936) reported on its action on normal and malignant cells in vitro and in vivo. He is credited with having pointed out that the inhibitory action of colchicine on mitosis is not at the onset, but in the metaphase. Any one microscopic slide will show an increased number of cells in mitosis, but this apparent stimulative effect, as first suggested by Dustin and his co-workers, was shown by Ludford to be merely an accumulation of the arrested cells. Ludford showed at an early date that the effective dose was unfortunately at or only just below the lethal dose. Havas (1937) and Gavaudan (1937) were the first to show the effect of colchicine on the germination of wheat seeds and the growth of seedlings, and the extent to which a parallelism can be found in this regard between animal and plant cells. Brues (1936), Brues and Marble (1937), Brues and Cohen (1936), and Brues and others (1940), investigated the effects of colchicine on the regenerating liver of the rat following partial hepatectomy, and used this observation to develop a method of measuring the anti-mitotic action of any particular drug. Allen and others (1936), working at the Yale Medical School, introduced these effects to endocrinologists, pointing out the application of the colchicine effect to hormone study and assay. The investigations in America culminated in the successful demonstration of polyploidy (chromosomal division without cell division) in plants by Blakeslee (1937), Blakeslee and Avery (1937), Nebel (1937), Nebel and Ruttle (1938), Eigsti (1947), and many others, and suggested the possibility of developing new species through the application of a drug like colchicine. The subsequent literature of colchicine and related compounds while voluminous (Eigsti, 1947) mainly centres in problems in other fields than that of gout.

The most recent significant advance in our knowledge of colchicum was the production of radioactive colchicine, randomly labelled with carbon C-14 by the biosynthetic procedures developed by Geiling, Kelsey, McIntosh, and Ganz (1948). This radioactive preparation was used by Back and others
(1951) at the same laboratory to trace the fate of colchicine in vivo.

\section{Suggestions for Future Investigations}

A summary of useful suggestions that may be gleaned from this brief history appears to be worthwhile. It might be fruitful to investigate the effect of the other ingredients of colchicum corm, continuing the work of Šantavý and Reichstein (1950); the content of the corm at various times of the year; the content and type of drug present in fresh corms and in corms "dried over 6 months"; the effect of colchicum as a diuretic; a clinical trial of the conjoined use of carminatives and cathartics with colchicine, as was the custom with the ancients, rather than the administration of paregoric to allay the final diarrhoea as is at times the practice to-day; a re-investigation of the use in gout of hellebore (veratrum) which appears now to have a synergistic effect with colchicum; the application of colchicine locally for its effect on tumours (Nelson, 1951) and ulcers, and for its possible systemic effect in arthritis when locally applied (Carr, 1951); and the possibility of poisoning through prolonged administration in chronic gout. The metabolism and the mode of action of colchicine in gout is an open field for research.

Many references to the history of colchicum in current medical literature are erroneous and these errors have been carried over from article to article. We hope we have corrected some of these without adding others of our own.

\section{Summary}

The use of colchicum first as a poison and later in the treatment of gout can be traced back at least 2,000 years. The new hormones, cortisone and ACTH have by no means usurped the ancient and useful position of this drug.

The most important known effect of colchicum which is to inhibit completion of mitosis or the division of cells, may or may not be related to its favourable effect on an acute attack of gout. Other theories as to its mode of action in gout have been proposed, but without sufficient evidence to establish their validity.

The toxicology of colchicum is unique in that it produces its lethal effects slowly, requiring a number of hours to cause death in carnivora, and longer in herbivora. Some poikilotherms are practically immune to its toxic effects, unless artificially heated.

Colchicum autumnale L., from which colchicum is 
obtained, is a perennial plant of the Lily family, and must not be confused with the Crocuses, which are of the Iris family and contain no colchicum.

It is probable that colchicum was known to the early Greeks under the term Ephemeron "which some call Colchicon". It was first referred to, and as a poison, by Theophrastus, and subsequently by Dioscorides, from whose "Herbal" two pictures of Ephemeron are reproduced in this text.

Alexander of Tralles (c. A.D. 550) in his "Therapeutica", made no mention of either ephemeron or colchicum, but recommended hermodactyl as the drug of choice. He gave no botanical description and the real identity of hermodactyl is in dispute. The reasons in favour of identifying hermodactyl with colchicumare first that the indications and effects appear similar, and second that Alexander does not once mention colchicum or ephemeron, a notable fact in that he was naturally familiar with the "Herbal" of Dioscorides.

The Arabic physicians introduced a new term, surugen, and later made all three terms synonymous. Serapion said that "Surugen is Hermodactyl" and that "Hermodactyl is also called Achimeron". The Arabs recommended this Surugen for the treatment of arthritis.

Meanwhile, in Central Europe, probably during the late Middle Ages, a new term-herbstzeitlosedeveloped, and this was recommended for the treatment of gout. The controversy as to the identification of herbzeitlose with ephemeron, colchicum, and surugen, which immediately arose lasted until the 19th century. The bulk of evidence appears to support the thesis that these terms are synonymous.

The use of these plants in gout underwent great fluctuations in popularity. As hermodactyl the drug was used in gout by the Byzantines, and as surugen it was used by the Arabs. As hermodactyl it appeared in the earliest English medical literature, and as herbstzeitlose in that of Central Europe. By the 15 th century, however, its use in gout had fallen into great disrepute, because of the secondary toxic manifestations which physicians had difficulty in controlling. As a result almost all the physicians of the 17th and 18th centuries ignored colchicum in the treatment of gout.

The modern history of the use of colchicum in gout starts with Nicolas Husson, not a physician but an officer in the French Army, who concocted a panacea called "Eau Medicinale", the active ingredient of which was found to be colchicum. With the writings of Scudamore (1819) colchicum became the established treatment for acute attacks of gout. This opinion was supported by the elder Garrod, since whose time very little new has been learned about the administration or mode of action $\frac{\mathbb{D}}{5}$ of the drug.

The effect of colchicum in arresting mitosis has $\frac{0}{\infty}$ been used experimentally in tumour research, start ing with Dustin and his associates in 1933. This work has had profound significance in cancero research, as well as in many other fields, such as $\frac{\overline{\underline{\sigma}}}{\overline{\mathrm{O}}}$ endocrinology, genetics and cytology.

A study of the history of colchicum brings to light $\stackrel{\oplus}{\varnothing}$ many still unsolved problems related to its isolation, administration, and pharmacodynamics, and the $\rightarrow$ metabolism and the mode of action of colchicum in gout is an open field for research.

\section{REFERENCES}

Adams, F., ed. (1834-47). “Epitome” of Paul of Aegina. Sydenham. $\vec{\omega}$

Society, London.
(1856). "The Extant Works of Aretaeus the Cappodocian". Sydenham Society, London. "Therapeutica", ed. T. PuschAlexander of Tralles (6th cent. A.D.). "Therapeutica", ed. T. Pusch-O
mann (1879). Allen, E., Smith, G. M., and Gardner, W. U. (1936). Anat. Rec., 금

Amoroso, E. C. (1935). Nature (Lond.), 135, 266.

Aretaeus Cappadox (2nd cent. A.D.). "The Extant Works of Aretaeus the Cappadocian", ed. and trans. F. Adams (1856).

Arnstein, H. R. V., Tarbell, D. S., Huang, H. T., and Scott, G. P. (1948). J. Amer. chem. Soc., 70, 1669.

$\overline{\text { Ashley, J. N., and Harris, J. O. (1944). J. chem. Soc. (Lond.) }}$ December, p. 677 .

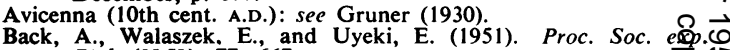
Biol. (N.Y.), 77, 667 .

Bauhin, C. (16th cent.): see Rüegg (1936).

Blackmore, R. (1726). "Discourses on the Gout, Rheumatism the King's Evil"'. Pemberton, London.

Blakeslee, A. F. (1937). C.R. Acad. Sci. (Paris), 205, 476.

- , and Avery, A. G. (1937). J. Hered., 28, 393.

Bock, H. (15th cent.): see Rüegg (1936).

Bowles, E. A. (1924). "A Handbook of Crocus and Colchicum forn the Gardener". Hopkinson, London.

Brues, A. M. (1936). J. Physiol. (Lond.), 86, 63P.

and Cohen, A. (1936). Biochem. J., 30, 1363.

and Marble, B. B. (1937). J. exp. Med., 65, 15. Addendum, 38, 190 .

Brunfels, O. (15th cent.): see Rüegg (1936).

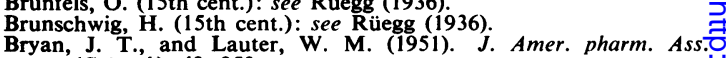
(Sci. ed.), 40, 253.

Cadogan, W. (1772). "A Dissertation on the Gout, and all Chronicol Diseases, Jointly Considered", 10th ed. Knox, Boston;을 Dodsley, London.

Carr, J. (1951). Practitioner, 166, 595.

Čech, J., and Santavy, F. (1949). Coll. Trar. chim. Tchécosl. $14,532$.

Clark, J.' Y. (1818). Amer. med. Recorder (Phila.), 1, 369.

Cook, J. W. (1945). Nature (Lond.), 155, 479.

Cordus, E. (15th cent.): see Rüegg (1936).

Culpeper, N. (1653). "The English Physician Enlarged". Saw-음 bridge, London.

(1947). "English Physician and Complete Herbal", arrangedD for use as a First-Aid Herbal, by Mrs. C. F. Leyel. Joseph,

London.
Demetrius Pepagomenus (c. 1282). "Liber de podagra, et id genus $\mathrm{N}$ morbis", Parisiis. Apud guil. Morelium, 1558. O

Dewar, M. J.'S. (1945). Nature (Lond.), 155, 141. Comment by" Cook (1945).

Dicker, S. E. (1951). Brit. J. Pharmacol., 6, 169.

Dioscorides Anazarbeus, Pedacius (1st and 2nd cent. A.D.). "DeN materia medica". Codex Anicae Julianae, ed. Sijthoff (1906). "De materia medica libri VII 3 accedunt Nicandri et Eutecnij opuscula medica". Codex Constantino politanus saeculo asservatus, Lutetiae Parisiorum: [n.p.] 1935, 2v. bibliothecae "Greek Herbal", trans. J. Goodyer (1655), ed. R. T. Gunther Dixon, W. E. (1915). "A Manual of Pharmacology", 4th ed . 
Dixon, W. E., and Malden, W. (1908) J. Physiol (Lond.), 37, 50 Dustin, A. P., and Grégoire, C. (1933a). Bull. Acad. Méd. Belg., 13,585 .

1933b). C.R. Soc. Biol. (Paris), 114, 195.

Dodonaeus, R. (16th cent.): see Rüegg (1936).

Doering, W. von E., and Knox, L. H. (1951). J. Amer. chem. Soc. $73,828$.

Eigsti, O. J. (1947). “Colchicine Bibliography”, Lloydia, 10, 65.

Ferguson, F. C., Jr. (1952). J. Pharm. exp. Ther., 106, 261. MacCoun, Chicago; Stevens, London.

Dialogue between Franklin and the Gout, vol. 2, p. 194.

Mode of Relieving Pain of, vol. 8, p. 481.

Fuchs, L. (16th cent.): see Rüegg (1936).

Fühner, H. (1913). Arch. exp. Path. Pharmak., 72, 228.

Fuhrman, F. A. (1946). Physiol. Rev., 26, 247.

Galen (2nd cent. A.D.). "De simplicium medicamentorum temperamentis facultatibus", V.I.5.25 (ed. Kuhn).

Garrod, A. B. (1848). Med.-Chir. Trans. (Lond.), 31, 83.

1859) "The Nature and Treatment of Gout and Rheumatic Gout" Watson and Maberly, London

Gavaudan, N., and Pomriaskinsky-Kobozieff, N. (1937). C.R. Soc. Biol., 125, 705 .

Geiger, P. L. (1833). Liebigs Ann. Pharm., 7, 274

Geiling, E. M. K., Kelsey, F. E., McIntosh, B. J., and Ganz, A. (1948). Science, 108, 558 .

Geoffroy, S. F. (1741): see Rüegg (1936).

Greven, J. (1568): see Rüegg (1936).

Gilbertus Anglicus (1918). "Medicine of the Thirteenth Century", with a biography of the author by H. E. Handerson. The Cleveland Medical Library Association, Cleveland, Ohio.

Gohar, M. A., and Makkawi, M. (1951). J. Pharm. (Lond.), 3, 415. Goodyer, J. (1655). "Greek Herbal of Dioscorides". Oxford.

Gow, A. S. F., and Scholfield, A. F. (1953). "Alexipharmaca of Nicander", Cambridge University Press.

Gruner, O. (1930). "A Treatise on the Canon of Medicine of Avicenna". Luzac, London.

Gunther, R. T. (1934). "Greek Herbal of Dioscorides", englished by J. Goodyer. Oxford.

Haden, C. T. (1820). "Practical Observations on the Colchicum autumnale in Inflammatory Diseases as a Substitute for Bleeding", Burgess and Hill, London.

Halford, H. (1831). "Essays and Orations read and delivered at the Royal College of Physicians". Murray, London.

Hammond, W. A. (1861). A. med. Month. and N.Y. Rev., 15, 81.

Handerson, H. E., ed. (1918). "Medicine of the Thirteenth Century". Cleveland, Ohio.

Havas, L. (1937). Nature (Lond.), 139, 371

(1938). Growth, 2, 257

Heberden, W. (1802). "Commentarii de Morborum Historia et Curatione". Payne, London.

Hill, J. (1769). "The Family Practice of Physic". London.

Home, E. (1817). Philos. Trans., 107, 262.

Home, F. (1780). "Clinical Experiments, Histories, and Dissections". Crech, Edinburgh.

Hort, A. (1916). "Enquiry into Plants", vol. 2. Loeb Classical Library.

Horowitz, R. M., and Ullyot, G. E. (1952). Science, 115, 216.

Houdès, A. (1881). "Le colchique et la colchicine". Steinheil, Paris.

(1884). C.R. Acad. Sci. (Paris), 98, 1442.

Husson, N. (1783). "Collection de faits et recueil d'expériences sur le spécifique et les effets de l'eau médicinale". Brasseur, Bouillon.

Hutchison, R. (1934). Ann. med. Hist., N.S. 6, 56

Ibn-El-Beithar (12th cent. A.D.): see Rüegg (1936)

Jacobj, C. (1890). Arch. exp. Path. Pharmak., 27, 119.

Jones, E. G. (1810). "An Account of the Remarkable Effects of the Eau Medicinale d'Husson in the Gout", 2nd ed. White and Cochrane, London.

Kinglake, R. (1804). "A Dissertation on Gout". Murray, London. Krythe, J. M., and Wellensiek, S. J. (1942). Bibliogr. genet., 14, 1.

Lewis, W. (1761). "The Experimental History of the Materia Medica, or the Natural and Artificial Substances made use of in Medicine". Baldwin, London.

Leyel, C. F. ed. (1947). "The English Physician and Complete Herbal of Nicolas Culpeper". Joseph, London.

Linnaeus, C. (18th cent.): see Rüegg (1936).

Lits, F. (1934). C.R. Soc. Biol. (Paris), 115, 1421.

Ludford, R. J. (1936). Arch. exp. Zellforsch., 18, 411.

Maclagan, J. M. (1852). Monthly J. med. Sci. (Edin.), 14, 1.

Mansur, A. (10th cent. A.D.): see Rüegg (1936).

Mattioli, A. (10th cent. A.D.): see Rüegg (1936).

Mattioli, -. (16th cent.): see Rüegg (1936). J. Pharm. Pharmacol., 3, 486 .

Mesue, J. (10th cent. A.D.): see Rüegg (1936).

Nebel, B. R. (1937). Biol. Bull., 73, 351

, and Ruttle, M. L. (1938). Genetics, 23, 161.

Nelson, L. M. (1951). Arch. Derm. Syph. (Chicago), 63, 440.

Nicander (2nd cent. B.c.). "Alexipharmaca", P III Verse 250 , ed. A. S. F. Gow and A. F. Scholfield, 1953. Cambridge University Press, New York.
Oribasius (4th cent. A.D.): see Rüegg (1936)

Orsini, M. W., and Pansky, B. (1952). Science, 115, 88.

Paré, A. (1641). "Oeuvres", 10th ed., p. 424. Rigaud, Lyons.

Paul of Aegina (7th cent. A.D.). "Epitome", trans. F. Adams. Sydenham Society, London.

Pelletier, P. J., and Caventou, J. B. (1820). Ann. Chim. Phys., $14,69$.

Perrot, E. (1936). C.R. Acad. Sci. (Paris), 202, 1088

Pliny the Elder (ist cent. A.D.): see Rüegg (1936).

Puschmann, T., ed. (1879). "Alexander Von Tralles, Therapeutica". Bramüller, Wein.

Quincy, J. (1733). "A Complete English Dispensatory", 9th ed. Osborn, London.

Rüegg, K. (1936). "Beitraege zur Geschichte de offizinellen Drogen Crocus Acorus Calamus and Colchicum" (Diss. Phil. Basel). Schahl, Stetten/Basel.

Ryff, W. H. (1573): see Rüegg (1936).

Sanno, Y. (1911). Arch. exp. Path. Pharmak., 65, 325.

Santavý, F., and Reichstein, T. (1950). Helv. chim. acta, 33, 1606.

Schnitker, M. A. (1936). Bull. Inst. Hist. Med., 4, 89.

Schonack, W. (1912). "Die Rezeptsammlung des Scribonius Largus, Eine Kritische Studie". Fischer, Jena.

Scribonius Largus (1st cent. A.D.): see Schonack (1912)

Scudamore, C. (1819). "A Treatise on the Nature and Cure of Gout and Rheumatism", 3rd ed. Earle, Philadelphia.

Selye, H. (1949). Brit. med. J., 2, 1129.

Serapion Junior (11th cent. A.D.): see Rüegg (1936).

Sharp, G. (1909). Med. Mag. (Lond.), 18, 506,568

Sijthoff, A. W., ed. (1906). "Dioscorides' De materia medica", Codex Aniciae Julianae picturis illustratus nunc Vindobonensis Med. Gr. 1, phototypice editus: Moderante Josepho de Karabacek, praefati sunt Antonius de Premerstein, Carolus Wessely, Josephus Mantuani ... Lugd. Batav. 2 v. fol. (Codices graeci et latini photographice depicti duce Scatone de Vries tom 10.)

Stoerck, A. (1764). "An Essay on the Use and Effects of the Root of the Colchicum Autumnale, or Meadow-Saffron", trans. from Latin. Becket and De Hondt, London.

Sydenham, T. (1939). Med. Classics, 4, 304.

Theophratus Eresii (4th-3rd cent. B.C.). "Historia plantarum IX, 16.6". See Hort (1916).

United States of America Pharmacopeia (1950). 14th revision. Mack, Easton, Pa.

Walpole, H.'(18th cent.): see Hutchison (1934).

Want, J.' (1814). Med. phys. J. Lond., 32, 312.

Windaus, A. (1924). Liebigs Ann. Chemie, 439, 59.

Zeisel, S. (1883). Mh. Chem., 4, 162.

Histoire de l'emploi du colchique et des médicaments apparantés dans la goutte, avec des suggestions pour des recherches ultérieures

\section{RÉSUMÉ}

L'emploi du colchique-comme poison et plus tard dans le traitement de la goutte-remonte au moins à deux mille ans. Les nouvelles hormones, comme la cortisone et l'ACTH, n'ont nullement remplacé ce médicament utile et ancien.

L'effet du colchique le plus important qu'on connaisse, celui d'inhiber la phase terminale de la mitose ou de la division cellulaire, pourrait bien être lié à son effet favorable dans l'attaque aigu de goutte. D'autres théories existent sur son mode d'action dans la goutte, mais il manque de preuves suffisantes à leur appui.

La toxicologie du colchique est unique dans le sens que son effet mortel est lent, ne s'exerçant qu'au bout de plusieurs heures chez les carnivores et plus tard chez les herbivores. Certains animaux poikilothermes sont en fait à l'abri de ses effets toxiques, à moins qu'on ne les réchauffe.

Colchicum autumnale, d'où vient le médicament, est une plante vivace de la famille des liliacées; on ne la confondra pas avec le crocus qui est un iridacé et qui ne contient pas de colchicine.

Il est probable que les Grecs anciens ont déjà connu le colchique sous le nom d'ephemeron "que certains appellent Colchicon". Le premier à en faire mention comme poison fut Théophraste, suivi de Dioscoride; c'est de l" "Herbal" de ce dernier que nous reproduisons dans le texte les deux figures d'ephemeron.

Alexandre de Tralles (550 apr. J.C.) dans "Thera- 
peutica" ne fait mention ni d'ephemeron ni de colchique, mais recommande l'hermodactyl comme médicament de choix. Il ne donne pas de description botanique et l'identité de la plante qu'il décrit est en question. Deux raisons plaident en faveur de l'identité du hermodactyl et du colchique: tout d'abord les indications et les effets semblent similaires et, deuxièmement, Alexandre ne fait jamais mention de colchique ni d'ephemeron, ce qui est remarquable puisqu'il était censé de connaître l" "Herbal" de Dioscoride.

Les médecins arabes introduisirent un terme nouveau, surugen, et plus tard les trois termes devinrent pour eux synonimes. Serapion dit que "surugen est hermodactyl" et que "hermodactyl s'appelle aussi Achimeron". Les Arabes recommandèrent surugen contre l'arthrite.

En attendant, en Europe Centrale, probablement vers la fin du moyen âge, naquit un terme nouveau-Herbstzeitlose, recommandé contre la goutte. Une polémique concernant l'identité de Herbstzeitlose, ephemeron, surugen et colchique commença bientôt et se prolongea jusqu'au XIX-ème siècle. La plupart des preuves semble supporter la théorie de leur identité.

La vogue de cette plante contre la goutte subit de grandes fluctuations. Les Byzantins l'utilisèrent sous le nom de hermodactyl, les Arabes sous celui de surugen. L'ancienne littérature médicale anglaise mentionne hermodactyl, et celle de l'Europe Centrale Herbstzeitlose. $\mathrm{Au}$ XV-ème siècle, cependant, son emploi contre la goutte tomba en désuétude en raison des manifestations toxiques secondaires que les médecins d'alors eurent peine à juguler. En conséquence, presque tous les médecins du XVII-ème et XVIII-ème siècle ignorèrent le colchique dans le traitement de la goutte.

L'histoire moderne de l'emploi du colchique contre la goutte commence avec Nicolas Husson, officier de l'armée française et non pas médecin, qui confectionna une panacée, Eau Médicinale, dont l'ingrédient actif principal, comme on l'a su plus tard, fut le colchique. Cette plante occupa le premier rang dans le traitement de l'attaque de goutte avec les écrits de Scudamore (1819), supporté par Garrod ainé. Depuis le temps de ce dernier on a ajouté très peu à nos connaissances de la posologie et du mode d'action du colchique.

Le pouvoir du colchique d'arrêter la mitose fut appliqué dans les recherches de laboratoire sur les tumeurs, inaugurées par Dustin et collaborateurs en 1933. Leur travail eut une grande importance dans les recherches sur le cancer ainsi que dans d'autres domaines, telles que l'endocrinologie, la génétique, et la cytologie.

L'étude de l'histoire du colchique met en relief les nombreux problèmes posés par l'isolement, la posologie, et la pharmacodynamie du médicament. Le métabolisme et le mode d'action du colchique dans la goutte offrent ıoujours un champ des recherches.

Historia del empleo del cólchico y de medicamentos aliados en la gota con sugestiones para investigaciones ulteriores

\section{SUMARIO}

El uso del cólchico-como veneno y luego en el tratamiento de la gota-se conoce desde al menos 2.000 años. Las nuevas hormonas, como la cortisona o la ACTH, no usurparon de manera alguna la posición antigua y útil de este medicamento.

El más importante efecto del cólchico que se conozca, el de inhibir la fase terminal de la mitosis o de la división celular, estaría quizás en relación con su efecto favorable en el ataque agudo de la gota. Fueron emitidas otras teorías sobre el modo de acción del cólchico sobre la gota, pero sin pruebas suficientes de validez.

La toxicología del cólchico es única en que su efecto mortal es lento, ejerciéndose tan sólo después de algunas $\overrightarrow{\vec{F}}$ horas en los carnívoros y todavía más tarde en los herbívoros. Algunos animales poiquilotermos no sufren $\bar{C}$ practicamente sus efectos tóxicos a menos de calentarlos. 흐

Colchicum autumnale del cual viene el medicamento, $\overline{\bar{\omega}}$ es una planta vivaz de la familia liliácea, que no se debe $\vec{\Phi}$ confundir con el azafran que es un iridáceo.

Es probable que los griegos antiguos conocieron el cólchico con el nombre de ephemeron "que algunos ? llaman Colchicon". Primero a mencionarle, como $\vec{\circ}$ veneno, fué Teofrasto; le siguió Dioscorides, de cuyo "Herbal" se reproducen aqui las dos figuras de ephemeron. $\vec{\omega}$

Alejandro Traliano (550 A.C.) en su "Therapeutica" no hace mención de ephemeron ni de cólchico pero recomenda hermodactyl como medicamento de elección. ? Faltando la descripción botánica, su identidad es opin- $\vec{\omega}$ able, pero existen dos razones en favor de la tesis que $\omega$ hermodactyl y cólchico son idènticos: las indicaciones y $\vec{\bullet}$ los efectos parecen similares y, además, Alejandro nunca $\mathscr{O}$ menciona el cólchico o el ephemeron, hecho notable ya $\circ$ que naturalmente conocía el "Herbal" de Dioscorides.

Los médicos árabes introdujeron un término nuevo, $\vec{c}$ surugen, haciendo sinónimos los tres términos. Serapion $\mathbb{D}$ dijo que "surugen es hermodactyl" y que "hermodactyl se llama también Achimeron". Los árabes recomendaron $\mathbb{D}$ surugen para artritis.

Entretanto en Europa Central, probablemente hacia $\mathbb{D}$ los fines de la edad media, nació un término nuevo-

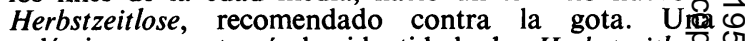
polémica respecto á la identidad de Herbstzeitlose, ephemeron, surugen y cólchico empezó muy pront $\overline{\mathrm{g}}$; prolongándose hasta el XIX siglo. La mayoría de ॠ্ pruebas parece soportar la teoría de su identidad.

La boga de esta planta contra la gota sufrió grandes fluctuaciones. Como hermodactyl la emplearon los bizantinos y como surugen los árabes. La antigua $\frac{\circ}{8}$ literatura médica inglesa menciona hermodactyl y la de $\varrho$ la Europa Central Herbstzeitlose. En el siglo XV, sin $\overrightarrow{\vec{F}}$ embargo, su empleo contra la gota sufrió descrédito a causa de manifestaciones tóxicas secundarias que los médicos tuvieron dificuldad en controlar. En consecuencia, casi todos los médicos del XVII y del XVIII siglo ignoraron el cólchico en el tratamiento de la gota.

La historia moderna del empleo del cólchico contra la gota empieza con Nicolas Husson, que no era médico $\bar{\sigma}$ sino oficial del ejército francés, quien confeccionó una 3 panacea, Eau Médicinale; se supo más tarde que su ingrediente activo principal fué cólchico. Esta planta ocupó el primer lugar en el tratamiento del ataque de $₹$ gota con los escritos de Scudamore (1819), soportado por응 Garrod mayor. Desde los tiempos de éste poco fué añadido a nuestros conocimientos de posología y del $\frac{D}{0}$ modo de acción del cólchico.

El efecto del cólchico de parar la mitosis fué aplicado experimentalmente en la investigación de los tumores, $\sigma$ empezando con Dustin y sus colaboradores en 1933. N Esta obra tuvo gran importancia en la investigación del $\mathrm{N}$ cáncer así como en muchos otros dominios, comow endocrinología, genética y citología.

El estudio de la historia del cólchico pone de relieve problemas que quedan por solver respecto al aislamiento, posología y farmacodinamia. Asimismo, el metaabren un campo de investigación. 